\title{
СИНТЕЗ И ИССЛЕДОВАНИЕ БИОЛОГИЧЕСКИ АКТИВНЫХ ПРОИЗВОДНЫХ 2-ОКСИНДОЛА
}

\author{
P.О. Еремеев, А.М. Ефремов, Е.Н. Безсонова \\ Московский государственный университет имени М.В.Ломоносова, \\ Химический факультет, Москва, Россия
}

DOI: 10.19163/MedChemRussia2021-2021-402

E-mail: roma.chem.dep@mail.ru

В медицине широко описано такое заболевание как глаукома, приводящее к необратимой слепоте. При глаукоме происходит повреждение зрительного нерва, причиной которого является повышение внутриглазного давления (ВГД). В нашей лаборатории было показано, что производные 2-оксиндола способны понижать ВГД, что позволяет использовать их для терапии глаукомы [1].

В работе [2] описан (5-метоксикарбониламино-2-оксиндол-3-ил)ацетонитрил, показавший наибольшую активность на нормотензивных кроликах (АВГД, \% (время макс. эфф., ч) $=41 \pm 7)$. Его эффект превышал как эффект мелатонина, так и эффект стандартного гипотензивного лекарства - тимолола.<smiles>COC(=O)Nc1ccc2c(c1)C(CC#N)C(=O)N2</smiles>

Поскольку синтез этого соединения протекал либо с невысоким выходом, либо требовал реализации семи стадий, в данном исследовании разработана методика получения и выделения промежуточных аминов, а также (метоксикарбониламино-2-оксиндол-3-ил) уксусных кислот и (метоксикарбониламино-2-оксиндол-3-ил)ацетонитрилов с хорошими выходами, без использования защитных групп и с меньшим количеством стадий (4 стадии).

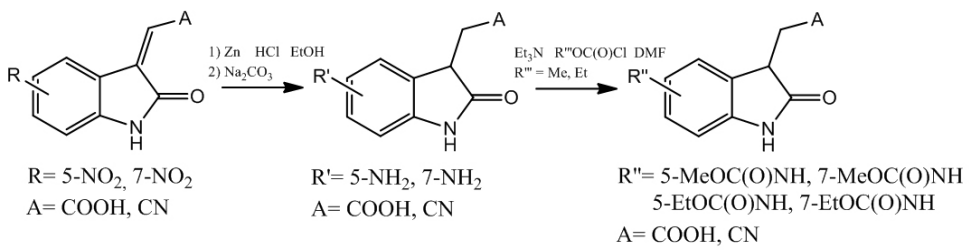

Активность всех полученных соединений изучена in vivo совместно с НИИ Глазных Болезней им. Гельмгольца.

Работа выполнена при поддержке гранта РФФИ (проект 20-03-00915)

\section{Литература}

1. Zaryanova E.V., Lozinskaya N.A., Beznos O.V., Volkova M.S., Chesnokova N.B., Zefirov N.S. Oxindole-based intraocular pressure reducing agents // Bioorg Med Chem Lett. 2017; Vol. 27(16), P:3787-3793.

2. Зарянова Е. В. Новые производные 2-оксиндола: синтез и перспективы применения в качестве лекарственных препаратов //Диссертация на соискание ученой степени кандидата химических наук. 2019. 